\title{
Bioregulators on seed germination and seedling growth of sweet basil
}

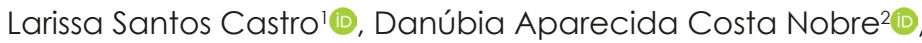 \\ Daniel Andrés Villegas Hurtado' $[$, Willian Rodrigues Macedo $*$ (i) \\ 'Federal University of Viçosa, Rio Paranaíba, Brazil \\ ${ }^{2}$ Federal University of Jequitinhonha and Mucuri Valleys, Diamantina, Brazil \\ *Corresponding author, e-mail: wrmacedo@ufv.br
}

\begin{abstract}
Basil (Ocimum basilicum L.) plants have multiple uses, ranging from spice to cosmetic purpose, besides being a source of essential oil and aromatic. These plants were commonly propagated by seed, however, few agrotechnologies are used to enhance the seed germination and initial growth in this crop. For this reason, our research aimed to evaluate aspects of seed germination of Ocimum basilicum L. cv. Limoncino, subjected to different bioregulators applied via substrate imbibition. The experiment was carried out in completely randomized design, with four treatments, as follows: T1: control (distilled water), T2: T13 a solution of a product formulated based on indolbutyric acid + naphthalene acetic acid + gibberellic acid (0.2 $\mathrm{mL} \mathrm{L}^{-1}$, Liko Química), T3: gibberellic acid $\left(0.5 \mathrm{mM} \mathrm{L}^{-1}\right.$, progibb- $\left.400^{\circledR}\right)$ and T4: brassinosteroids $\left(0.1 \mathrm{mM} \mathrm{L}^{-1}\right)$. We evaluated: germination rate, germination speed index (GSI), first count, root and shoot length and chlorophyll a, b, total and carotenoids. The bioregulators did not influence germination, first count, GSI and photosynthetic leaf pigment, but application of gibberellic acid and brassinosteroids improve the shoot and root length, respectively. The gibberellic acid and brassinosteroids are promising bioregulators for stimulating initial basil growth.
\end{abstract}

Keywords: Auxin, brassinosteroids, gibberellin, Ocimum basilicum L., medicinal plants

Sweet basil (Ocimum basilicum L.), is a specie of the Lamiaceae family, cultivated throughout the world, source of essential oil appreciated by the industry for its flavor and fragrance (Singh et al., 2014). Being interesting for the production of cosmetics (Dorni et al., 2017), as well as agricultural purposes, with insecticidal, nematicidal, fungicidal and antimicrobial properties (Singh et al., 2014).

However, the germination of medicinal seeds, particularly for sweet basil, is limited by intrinsic and extrinsic factors (Elhindi et al., 2016), as environmental conditions (Zhou et al., 2016) or seed dormancy (Amaro et al., 2012), considering that physiology of basil seed germination is a biological complex process, and is one of the most important stages of the plant life cycle (Kumar, 2012), it is necessary to improve the seed vigor and initial growth of the plants. For this reason, the use of bioregulators can enhance seed germination and initial seedling performance, because these compounds also participate in the regulation of seed maturity, dormancy, and germination (Elhindi et al., 2016).

Therefore, the present study aimed to evaluate the effect of the bioregulators brassinosteroids, gibberellic acid, and a formulation of indolbutyric acid + naphthalene acetic acid + gibberellin on the germination physiology and performance of basil seedlings.

The experiment was carried out at the Crop Physiology and Metabolism Laboratory (LAFIMEPRO), Federal University of Viçosa - Campus Rio Paranaíba, from September to October 2018. Commercial seeds of basil (Ocimum basilicum L.) cv. Limoncino (ISLA Seeds) were purchased from local suppliers and their characteristics are the following: $100 \%$ purity, $82 \%$ germination, batch number 115518-000.

The experiment was arranged in a completely randomized design with four treatments and eight 
replications. The treatments consisted of: T1 - control (soaking in distilled water only); T2 - T13 solution (noncommercial formulation, based on gibberellin plus auxins), soaking in a solution of the formulation indolbutyric acid + naphthalene acetic acid + gibberellic acid $\left(0.2 \mathrm{~mL} \mathrm{~L}^{-1}\right.$ - Liko Química); T3 - gibberellic acid $(0.5$ $\mathrm{mM} \mathrm{L}^{-1}$ progibb - 400); and T4 - brassinosteroids $\left(0.1 \mathrm{mM} \mathrm{L}^{-1}\right.$ 24-epibrassinolide). The doses were adjusted according review in the scientific literature (data not showed).

The variables germination, first germination count, germination speed index, shoot and root length, and leaf pigment content were analyzed.

Germination test was conducted in Biochemical Oxygen Demand (B.O.D.) germinators regulated to an average temperature of $25^{\circ} \mathrm{C}\left( \pm 5^{\circ} \mathrm{C}\right)$ in a 24 -hour cycle, with 8-h photoperiod, according to the Seed Analysis Rules (Brasil, 2009). For this test, 25 seeds were distributed on germites ${ }^{\circledR}$ paper sheets and soaked with the respective treatment solutions equivalent to 2.5 times the weight of the dry substrate (Brasil, 2009).

The first count test was conducted along with the germination tests and germination speed index, by computing normal seedlings, where, according to Seed Analysis Rules (Brasil, 2009), the evaluation of basil is performed at 4 and 14 days after test set up.

The germination speed index (GSI) consisted of daily counts of normal seedlings until stabilization of counts, performed when the seeds were approximately $3 \mathrm{~mm}$ in radicle length. At the end of the test, with daily data and the respective counts of emerged seedlings, the GSI was calculated using the formula proposed by Maguire (1962):

$$
G S I=\frac{G 1}{N 1}+\frac{G 2}{N 2}+\cdots \frac{G n}{N n}
$$

Where:

GSI = germination speed index;

G1, G2, ... Gn = number of normal seedlings computed at the first count, the second count, ... and the last count; $\mathrm{N} 1, \mathrm{~N} 2, \ldots \mathrm{Nn}=$ number of days from sowing to first, second, ... and last count.

The biometric measurement and pigments analysis, of normal and well-established plantlets, were carried out at eight days, using eight replicates for each treatment, to evaluate the initial growth and development. The shoot and root lengths were measured with a graduated scale. And after these measurements, $0.1 \mathrm{~g}$ of leaf tissue was collected for analysis of leaf pigment contents, placed in plastic tubes $(50 \mathrm{~mL})$ containing $80 \%$
( $v / v)$ acetone solution, and kept in the dark 72 hours (Macedo et al., 2013). The absorbance of supernatant was read at 645 and $663 \mathrm{~nm}$ in a spectrophotometer (SP2000 UV Spectrum) to determine chlorophyll $a ; b$, and total, and at $470 \mathrm{~nm}$ to determine carotenoid (Witham et al., 1971). Results were expressed as milligrams of pigment per gram fresh leaf tissue ( $\mathrm{mg} \mathrm{g}^{-1} \mathrm{FM}$ ).

The results were subjected to analysis of variance (ANOVA) and the means compared by the StudentNewman-Keuls (SNK) test at $5 \%$ probability, using the Speed Stat spreadsheet program ${ }^{\circledR}$, version 2.2 .

The seeds formed a mucilage layer around the integument after around 15 seconds in contact with the moist germitest ${ }^{\oplus}$ paper, still during the preparation of the germination test. According to Yang et al. (2012), the mucilage adhered to seeds can delayed the germination, because it is an oxygen barrier, as already reported for Alysssum minus seed (Ying et al., 2012), and which would explain the seed dormancy in basil. Studies have reported reduction in seed germination percentage due to the presence of mucilage in Hylocereus undatus (Godoy et al., 2012) and Theobroma cacao (Adu et al., 2017), however contrasting results showing an important function of mucilage on seed moisture uptake from arid and semiarid environment (Bhatt et al., 2016), or protect seeds against abiotic stress (Geneve et al., 2017).

The results of germination (Figure 1A), germination speed index (Figure 1B), and the first germination count (Figure 1C) showed no significant differences, between the treatments.

However, we observed that the treatment with gibberellic acid had gains of $6.86 \%$ for germination rate; $0.63 \%$ for GSl; and $10 \%$ for first count, in comparison with the lowest means found in the study. Considering that the seeds are relatively small, this higher percentage can reduce losses when direct sowing in the field is carried out, ensuring a proper stand. Mostly the studies showed that the application of gibberellic acid to seeds, or by pre-imbibition, increases the amount of germinated seeds and accelerates germination (Elhindi et al., 2016; Murakami et al., 2011), we verified a tendency of this behavior, but without statistical significance. The higher the GSI, the greater the possibility of obtaining more vigorous seedlings in a shorter period of time, which can be verified by the same data behavior in results of the first count.

For biometric analysis root length and shoot length (Figure 2) we visualized distinct patterns of response.

The root length (Figure 2A) varied among treatments, with the highest mean recorded in the 

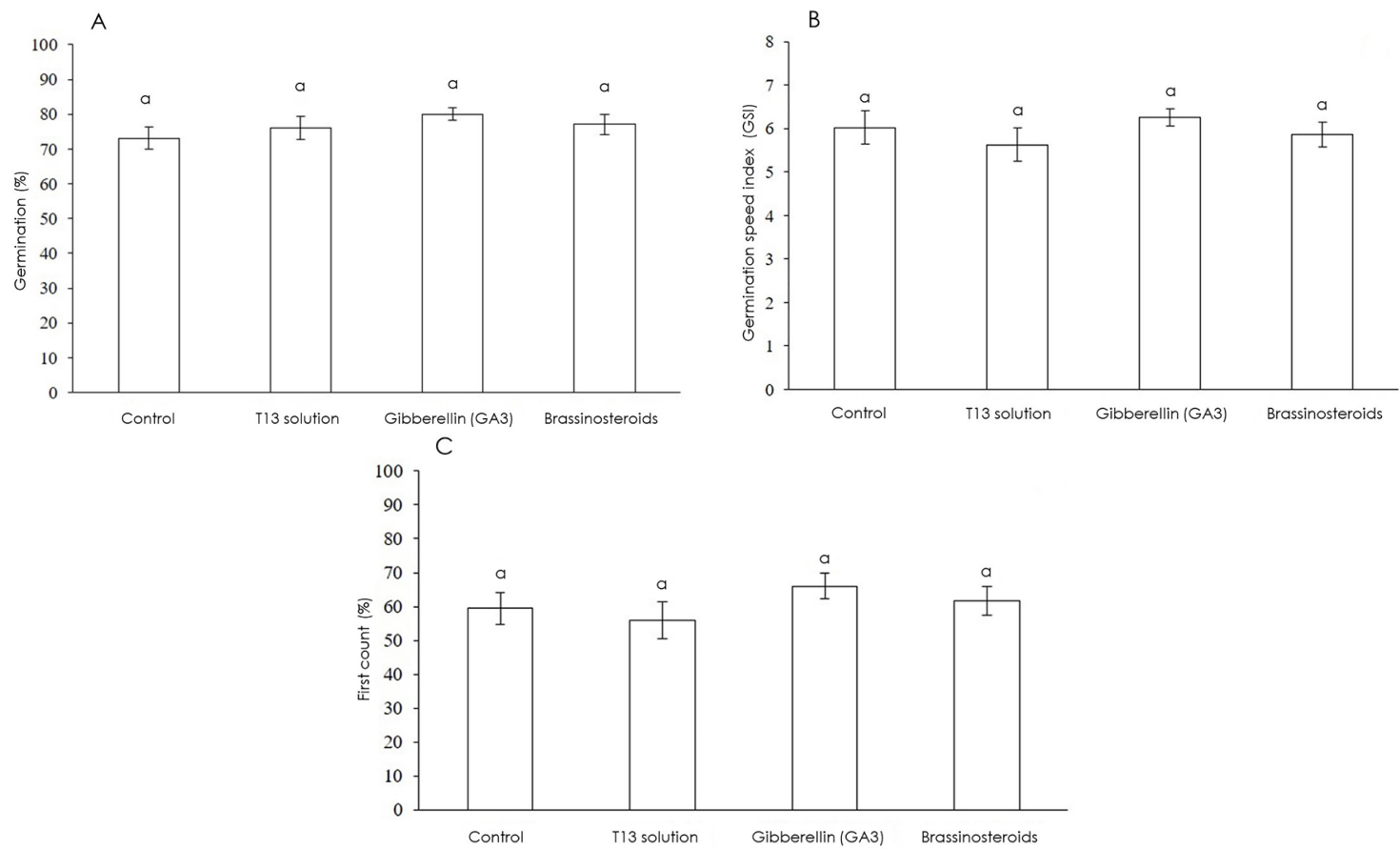

Figure 1. Germination (A), germination speed index (B) e first count of germination (C) of sweet basil seeds subjected to different bioregulators. Means followed by the same letter do not differ by SNK test (5\%).

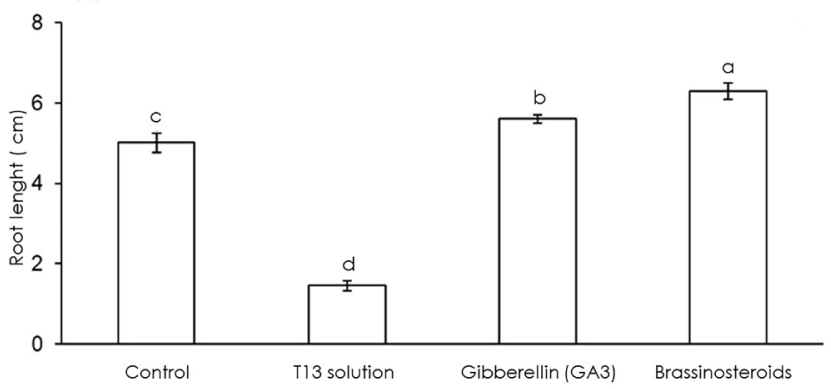

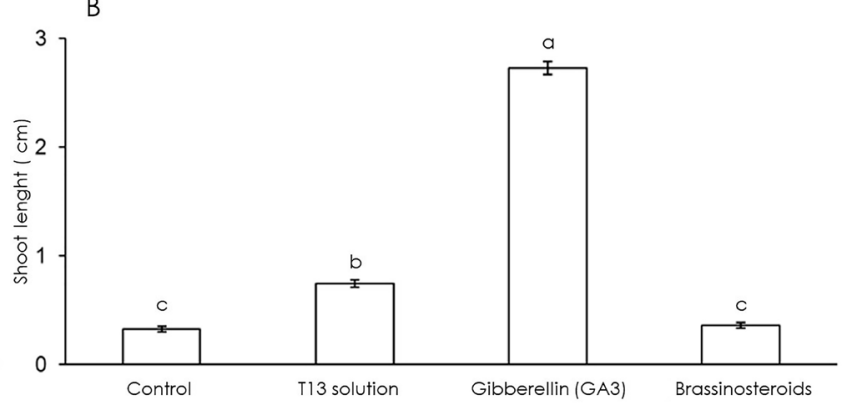

Figure 2. Root lenght (A) e shoot lenght (B) of sweet basil plantlets subjected to different bioregulators. Means followed by the same letter do not differ by SNK test (5\%).

treatment with brassinosteroids applied to the substrate, while the lowest mean was found in the treatment formulated with auxins and gibberellin (T13 solution). It was expected because brassinosteroids are plant hormones that regulate processes of cell elongation and xylem differentiation, with responses in root and stem elongation, seed germination, and apical dominance (Grove et al., 1979; Asci et al., 2019).

Examining the composition of the T13 solution, with two types of synthetic auxins (indolbutyric acid + naphthalene acetic acid), and considering that the plant still produces endogenous auxin, the shorter root length (Figure 2A) may be a cause of phytotoxicity caused by this combination of hormones, which probably accumulated in a high concentration within the plant.

Regarding shoot length (Figure 2B), the application of gibberellic acid favored growth, showing a difference of $88.08 \%$ higher than the lowest mean (control). Previous research with basil seeds treated with gibberellic acid has been proven that this bioregulator to stimulate germination and initial growth (Elhindi et al., 2016).

This study found significant differences in leaf pigment contents between the treatments, we observed that chlorophyll a content it was higher in control (Figure $3 \mathrm{~A}$ ), as chlorophyll b (Figure 3B), total chlorophyll Figure $3 C$ ) and carotenoids (Figure 3D). Whereas the gibberellin $\left(G A_{3}\right)$ treatment showed the worst averages for chlorophyll a (Figure 3A), chlorophyll b (Figure 3B), total chlorophyll Figure $3 C$ ) and carotenoids (Figure $3 D$ ). We found that highest contents of photosynthetic pigments occurred in the absence of bioregulators. These compounds can be altering the leaf growth and leaf pigments content in basil plants (Divya Nair, 2009), mostly in developed plants. Furthermore, plant responses to bioregulators may vary by species, stage of development, endogenous hormonal balance, and age (Aftab et al., 2010; Idrees et al., 2010; Idrees et al., 2011; Naeem et al., 2011). 

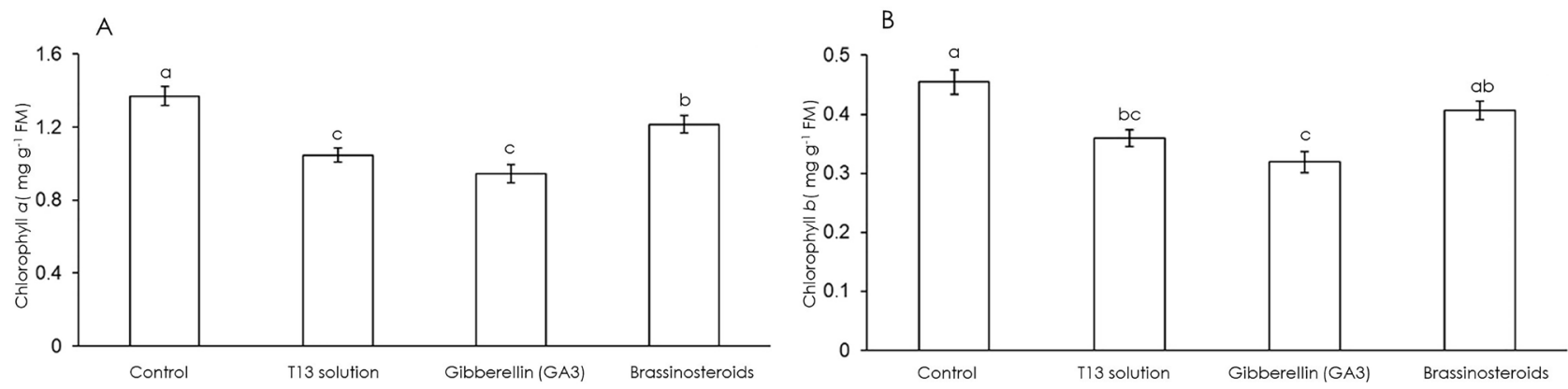

$$
\text { C }
$$
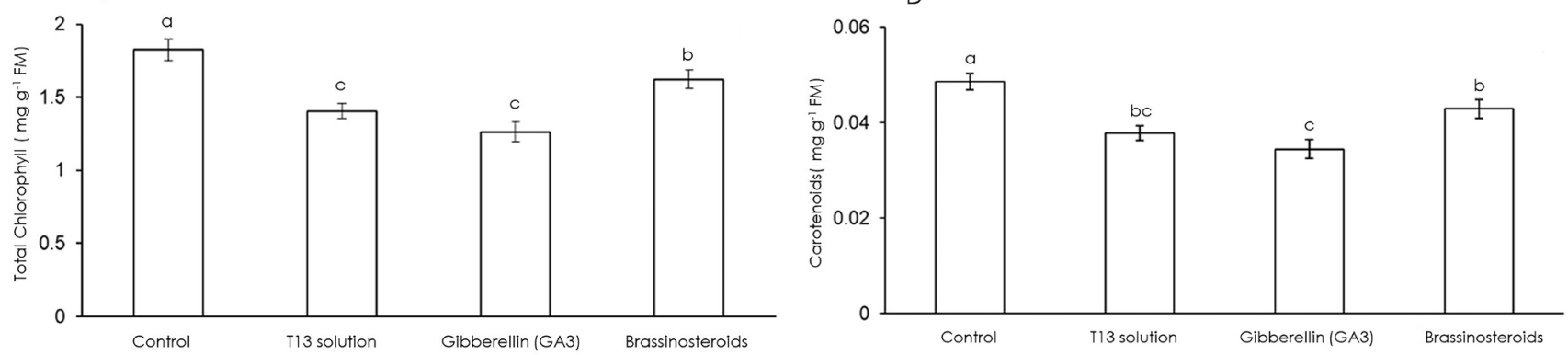

Figure 3. Photosynthetic pigments: chlorophyll a (A), chlorophyll b (B), total chlorophyll (C) and carotenoids (D) of sweet basil plantlets subjected to different bioregulators. Means followed by the same letter do not differ by SNK test (5\%).

The use of bioregulators $\left(\mathrm{GA}_{3}\right.$, brassinosteroids and new formulated bioregulator - T13) do not harm basil seed germination and were effective in promoting growth and development of seedlings. And different physiological responses in basil plantlets, were observed: the brassinosteroids stimulated the growth of roots and gibberellic acid stimulated the plant shoot.

\section{Acknowledgements}

This study was financed in part by the Coordenação de Aperfeiçoamento de Pessoal de Nível Superior - Brasil (CAPES) - Finance Code 001. And the authors are gratefully for financial support from the National Council for Scientific and Technological Development (CNPq, Conselho Nacional de Desenvolvimento Científico e Tecnológico), National Institute of Science and Technology - INCT BioNat, grant \# 465637/2014-0, Brazil.

\section{References}

Adu, M.O., Cobbinah, T., Asare, P.A., Yawson, D.O., Taah, K.J. 2017. Demucilaging freshly stored seeds of cocoa (Theobroma cacao L.) improves seedling emergence and growth. Journal of Botany 2017: 1-10.

Aftab, T., Khan, M.M., Idress, M., Naeem, M., Singh, M., Ram, M. 2010. Stimulation of crop productivity, photosynthesis and artemisinin production in Artemisia annua L. by triacontanol and gibberellic acid application. Journal of Plant Interactions 1: 273-281.

Amaro, H.T.R., Assis, M.O., David, A.M.S.S., Silveira, J.R., Silva Neta, I.C., Mota, W.F. 2012. Superação de dormência em sementes de manjericão (Ocimum basilicum L.). Revista Brasileira de Plantas Medicinais 14: 218-223.
Asci, Ö.A., Deveci, H., Erdeger, A., Özdemir, K.N., Demirci, T., Baydar, N.G. 2019. 'Brassinosteroids promote growth and secondary metabolite production in lavandin (Lavandula intermedia (Emeric ex Loisel.)'. Journal of Essential Oil Bearing Plants 22: 254-263.

Bhatt, A., Santo, A., Gallacher, D. 2016. Seed mucilage effect on water uptake and germination in five species from the hyper-arid Arabian desert. Journal of Arid Environments 128: 73-79.

BRASIL. Ministério da Agricultura, Pecuária e Abastecimento, 2009. Regras para análise de sementes. 1.ed. Mapa/ACS, Brasília, Brazil. 399 p.

Divya Nair, V., Jaleel, C.A., Gopi, R., Panneerselvam, R. 2009. Changes in growth and photosynthetic characteristics of Ocimum sanctum under growth regulator treatments. Frontiers of Biology in China 4: 192199.

Dorni, A.I.C., Amalraj, A., Gopi, S., Varma, K., Aanjana, S.N. 2017. Novel cosmeceuticals from plants - An industry guided review. Journal of Applied Research on Medicinal and Aromatic Plants 7: 1-26.

Elhindi, K.M., Dewir, Y.H., Asrar, A-W, Abdel-Salam, E., ElDin, A.S., Ali, M. 2016. Improvement of Seed Germination in Three Medicinal Plant Species by Plant Growth Regulators. HortScience 51: 887-891.

Geneve, R.L., Hildebrand, D.F., Phillips, T.D., AL-Amery, M., Kester S.T. 2017. Stress Influences Seed Germination in Mucilage-Producing Chia. Crop Science 57: 2160-2169.

Godoy, A.R., Alvez, C.Z., Oliveira, N.C. 2012. Efeito da remoção da mucilagem na germinação e vigor de sementes de Hylocereus undatus Haw. Revista Brasileira de Ciências Agrárias 7: 586-589.

Grove, M.D., Spencer, G.F., Rohwedder, W.K., Mandava, 
N., Worley, J.F., Warthen Júnior, J.D., Steffens, G.L., Flippen-Anderson, J.L., Cook J.C. 1979. Brassinolide, a plant growth-promoting esteroid isolated from Brassica napus pollen. Nature 12: 216-217.

Idrees, M., Khan, M.M., Aftab, T., Naeem, M., Hashmi, N. 2010. Salicylic acid-induced physiological and biochemical changes in lemongrass varieties under water stress. Journal of Plant Interactions 5: 293-303.

Idrees, M., Naeem, M., Aftab, T., Khan, M.M. 2011 . Salicylic acid mitigates salinity stress by improving antioxidant defence system and enhances vincristine and vinblastine alkaloids production in periwinkle [Catharanthus roseus (L.) G. Don]. Acta Physiologiae Plantarum 33: 987-999.

Kumar, B. 2012. Prediction of germination potential in seeds of Indian Basil (Ocimum basilicum L.). Journal of Crop Improvement 26: 532-539.

Macedo, W.R., Kitahara, D.K., Castro, P.R.C. 2013. Unravelling the physiologic and metabolic action of thiamethoxam on rice plants. Pesticide Biochemistry and Physiology 107: 244-249.

Maguire, J.D. 1962. Speed of germination - aid in selection and evaluation for seedling emergence and vigor. Crop Science 2: 176-177.

Murakami, D.M., Bizão, N., Vieira, R.D. 2011 . Quebra de dormência de semente de murici. Revista Brasileira de Fruticultura 33: 1257-1265.

Naeem, M., Khan, M.M.A., Idrees, M., Aftab, T. 2011. Triacontanol-mediated regulation of growth yield, physiological activities and active constituents of Mentha arvensis L. Plant Growth Regulation 65: 195-206.

Singh, K., Chand, S., Yaseen, M. 2014. Integrated nutrient management in Indian basil (Ocimum basilicum). Industrial Crops and Products 55: 225-229.

Witham, F.H., Blaydes, D.F., Devlin, R.M. 1971. Experiments in plant physiology. D. Van Nostrand, New York, USA. 245 p.

Yang, X., Baskin, J.M., Baskin, C.C., Huang, Z. 2012. More than just a coating: Ecological importance, taxonomic occurrence and phylogenetic relationships of seed coat mucilage. Perspectives in Plant Ecology, Evolution and Systematics 14: 434-442.

Ying, S., Dun, Y.T., Baskin, C.C., Baskin, J.M. 2012. Role of mucilage in seed dispersal and germination of the annual ephemeral Alyssum minus (Brassicaceae). Australian Journal of Botany 60: 439-449.

Zhou, D., Barney, J., Ponder, M.A., Welbaum, G.E. 2016. Germination response of six sweet basil (Ocimum basilicum) cultivars to temperature. Seed Technology 37: 43-51.
Conflict of Interest Statement: The authors declare that the research was conducted in the absence of any commercial or financial relationships that could be construed as a potential conflict of interest.

All the contents of this journal, except where otherwise noted, is licensed under a Creative Commons Attribution License attribuition-type BY. 